\title{
Generation and Proportion Assessment of Hospitals Infectious Waste in Bandung Region Indonesia
}

\author{
Novi Fitria ${ }^{1,2^{*}}$, Enri Damanhuri ${ }^{1}$, Indah Rachmatiah Siti Salami ${ }^{1}$, Venny Ulya Bunga ${ }^{1}$ and Yati Supriatin $^{2}$ \\ ${ }^{1}$ Doctoral Program of Environmental Engineering, Bandung Institute of Technology (ITB), Bandung - Indonesia \\ ${ }^{2}$ Department of Chemistry, Higher Education School of Analyst Bakti Asih, Bandung - Indonesia
}

\begin{abstract}
The accurate information about generation quantities of waste generated is a fundamental prerequisite for the successful implementation of any infectious waste management plan. The objectives of this study were to determine the quantity of generation rate and proportion of hospital infectious waste at Bandung region, Indonesia. The generation and proportion of infectious waste data were collected by using direct sampling method from 7 hospitals, which was completed for three days continuously in hospitals inpatient installation. Afterwards, average generation and proportion were determined in comparison to certain important organizational and functional factors, such as the number of beds, bed coverage, the value of infectious waste management and handling, accreditation status, waste handler status, ownership status, the different of type and the class of hospital. The way that source of infectious wastes, generated from hospitals, vary by functional factors, was also illustrated and the most important influenced factors were identified. Generated infectious hospital wastes vary from 0.22 to 1.26 $\mathrm{kg} /$ patient/day. Proportion infectious hospital wastes also vary from $8,88 \%$ to $47,37 \%$.
\end{abstract}

Keywords: Inpatient room; medical waste; generation rate; waste handling; waste management.

\section{Introduction}

Based on World Health Organization (WHO), $85 \%$ of all waste generated by healthcare facilities (hospital, clinic, and laboratory) is general waste or domestic waste, $15 \%$ others are include hazardous waste with proportion $10 \%$ infectious hazardous health care waste and 5\% chemical/radioactive hazardous health care waste [1]. The hazardous proportion only $15 \%$, but it may contain such pathogens material which can caused infectivity and other toxic, radioactive, carcinogenic, mutagenic or teratogenicity materials therefore a healthcare facilities requiring a safe management for their hazardous waste.

In 2015, Indonesian Ministry of Environment and Forestry, issues the law that established the policy to make some strategy of waste management that focus on preventing the generating of hazardous waste from healthcare facilities. Since its establishment, the healthcare facilities still attempted to adopt the law in their internal policy. Hospital is one of type from healthcare facilities. Hospitals are required to provide good services not only to the patients but also to ensure the safety of workers and the environment. Hospital waste based on Indonesian law regulation "PP 104/2014" about the management of hazardous and toxic wastes mention that hospital waste is a special waste, which is highly hazardous due to its infection and/or toxic capability. Workers and all member of public from hospital can directly exposed by infectious and/or toxic waste. All healthcare units had the same stages of problem in waste management plans, those stages are start from segregation, collection, packaging, storage, transport, treatment and disposal [2].

Waste management especially infectious waste management has become a critical issue as it poses potential health risk to the patient, worker, society and damage to the environment. In Indonesia, according to Indonesia Hospital Community the data show the estimation generation of medical waste \pm 366 Ton/day from 2.813 unit hospital all around Indonesia [3]. Furthermore to monitor the quantity and proportion of the waste must be done related to their infectious and/or toxic character. All steps of waste management system were monitored and evaluated. The issue areas of each steps will be presented here with influenced factors analysis in order to maintain and improve the existing conditions, and also to achieve a more effective, and more safety management of infectious waste. Looking into the existing condition of hospital infectious waste management in Bandung Region it was thought to

* Corresponding author: novie.fitria@gmail.com 
undertake study to : (i) assess the qualitative factor (hospital attribute) in handling and treatment of infectious waste; (ii) quantitatively determine the amount of infectious and non-infectious; (iii) analyze factor-factor that influence the generation and proportion of infectious waste from hospital.

\section{Material and Methods}

\subsection{Study area}

In Bandung area there were 35 hospitals with capacity 4941 beds. In order to represent the number of samples then calculated the number of beds representing the slovin formula. Based on the slovin calculations, from population 4941 beds, 370 beds are minimum number of bed that representing in this study. The sample was taken from 7 hospitals that have given permission to this research, from 7 hospitals we collected sample from 1001 beds. Thus the number of samples in this study has represented the population of hospital beds in Bandung. One of the hospitals has over 400 beds while the majority of them variety between 100 and 300 beds. There five hotels that determined as general hospital in this study. General hospital providing out-patients services diagnostic and medical treatment to in-patients, with a great varies of medical condition diagnostic [1]. In Indonesia the variety of diagnostic depend on the type hospitals. There are four types hospitals in Indonesia : Type A hospital (over 400 beds), type B hospital (between 300-400 beds), type C hospital (between 200300 beds) and type D (between 50-100 beds) hospital (both for general and specific hospital). The scoop of this study is calculated in-patient room generated waste at different type of hospital.

\subsection{Categories of infectious waste at hospital}

Determination quantities and proportion of hospital infection waste in-patient room become focus of study in this research. According to similar study, categories of hospital waste specially medical waste, divided into five categories [4], there are (a) all material that contain blood products and human blood (including plasma, blood plaster, blood cotton batting, pampers, etc); (b) Sharps (needles, scalpels, hypodermic needles, broken glasses, etc); (c) Pathological wastes (organs, human tissues, fluids, and other body parts); (d) Microbiological wastes (stocks suspected to contain pathogens and laboratory cultures); (d) Genotoxic wastes (cytotoxic wastes chemicals and cytotoxic drugs). In Indonesia medical waste from hospital divided into hazardous -infectious waste and Hazardous non - infectious waste. Base on regulation medical waste should be placed into different color of plastic bags. Yellow plastic bag for infectious waste, purple plastic bags for cytotoxic waste, brown plastic bag for pathology waste and red plastic bag for radioactive waste.

Before we start the study, we make a pilot hospital (RSAU. Salamun Hospital) to justify the generation of domestic waste and medical waste (infectious and non- infectious waste), the data showed in Fig.2. From total hospital waste $522,3 \mathrm{~kg} /$ day consist $397,14 \mathrm{~kg} /$ day domestic waste and $125,17 \mathrm{~kg} /$ day hazardous waste which include $12,35 \mathrm{~kg} /$ day non-infection waste and $112,82 \mathrm{~kg} /$ day infectious waste.

Domestic wastes have $76 \%$ from total hospital waste and $24 \%$ of hazardous waste, consists $22 \%$ infectious waste and $2 \%$ non-infectious waste. The data showed at Table 1.

Table 1. The source of infectious waste at hospital

\begin{tabular}{|c|c|}
\hline Source & $\begin{array}{c}\text { Infectious waste } \\
(\mathrm{kg} / \mathrm{day})\end{array}$ \\
\hline In-patient & 86,35 \\
\hline Out-patient & 2,46 \\
\hline ICU & 2,95 \\
\hline Laboratory & 1,13 \\
\hline Surgical room & 11,06 \\
\hline Emergency room & 6,25 \\
\hline HWWTP & 2,62 \\
\hline Total & 112,82 \\
\hline
\end{tabular}

In Bandung area the system of segregation hospital waste only divided into two groups which are the infectious and non-infectious waste will collecting in yellow plastic bag and domestic waste will be put in black plastic bag [5]. According to the data, in-patient rooms are the biggest source of infectious waste in hospital yet the laboratory is the smallest source of infectious waste. Therefore, the scoop of this research was at in-patient section, ICU, emergency section. In this study, the actual quantities of wastes were measured for three days in a row, using direct sampling methods at ward department (in-patient room). We collected and measure the medical waste and general waste. It is very not easy to applied the same measurement in several numbers of hospital unit services, that the reason we measure the variation on occupancy rate using equation total occupied bed $(\mathrm{O})$ divided with total number of beds (A) and then multiply with $100 \%$.

$$
\text { Bed occupancy rate }(B O R)=(O / A) \times 100 \%
$$

This research also observed the most influenced factors that affecting generation and proportion of infectious waste from hospital. The total of bed at hospital, the type of hospital, becomes important factors due to generation and proportion of hospital infectious waste. In order to minimize the possibility of variations due to bed occupied rate, the waste quantities were measured for three days continuously. This study 
conducted in month January - August in 2017, the permission research procedure in hospital were very difficult so it takes a long time to finish the sampling of generation and proportion waste in 7 hospitals at Bandung area.

\section{Results and Discussion}

\subsection{Generation rates of Hospital Infectious waste}

The generation rates of hospital infectious waste were collected from seven (7) hospitals in Bandung region. From 7 hospitals it consist 5 general hospitals and 2 specified hospitals. First we calculated the generation rates from all hospitals and then we also calculated the generation rates from general hospitals only. The analysis data used the scatter plot to determine the correlation coefficient (r) between total of beds due to infectious waste generation rates with scale $(\mathrm{kg} / \mathrm{day})$, and between total of occupied beds due to infectious waste generation rates with scale $(\mathrm{kg} / \mathrm{day})$.

The aim from this comparison is to analyzed, which one from the scale is more accurate to measure the infectious generation rates from hospital. The scatter plots showed that there is a significant correlation between total of beds with infectious generation rates. The value of coefficient correlation $(r)$ was gain by square rooted the $\mathrm{R}^{2}$ value. From the result, the number of occupied bed parameters gave the highest value of coefficient correlation in infectious generation rates from in-patient room. The scatter plots were presents in Fig.1, Fig 2, Fig. 3 and Fig 4.

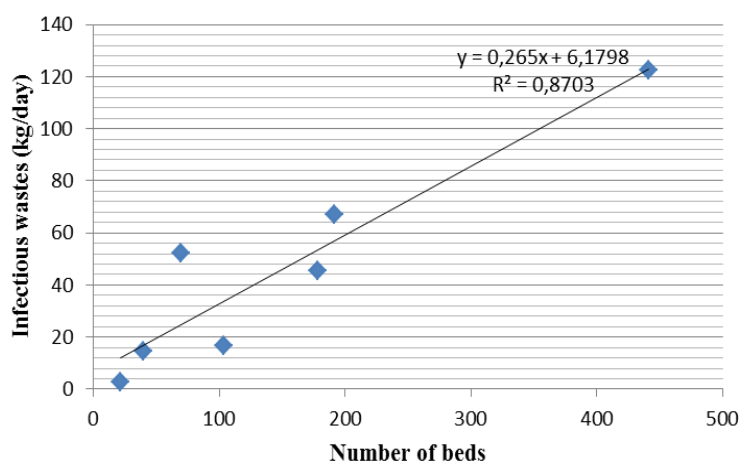

Fig.1. The correlation between infectious waste $(\mathrm{kg} / \mathrm{day})$ with total of beds (from 7 hospitals)

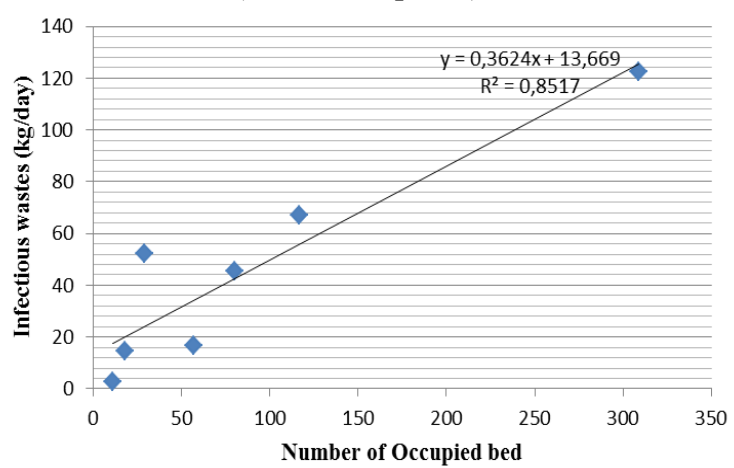

Fig.2. The correlation between infectious waste ( $\mathrm{kg} /$ day) with total of beds (from general hospitals only)

The scatter plot between total of beds and the generated quantities of infectious waste $(\mathrm{kg} /$ day) for all hospitals and for general hospital only showed that, there is a linier relationship with a better linier correlation coefficient $(\mathrm{r}=0,9376)$ with regression value $\mathrm{y}=0,2407 \mathrm{x}$ $+12,783$.

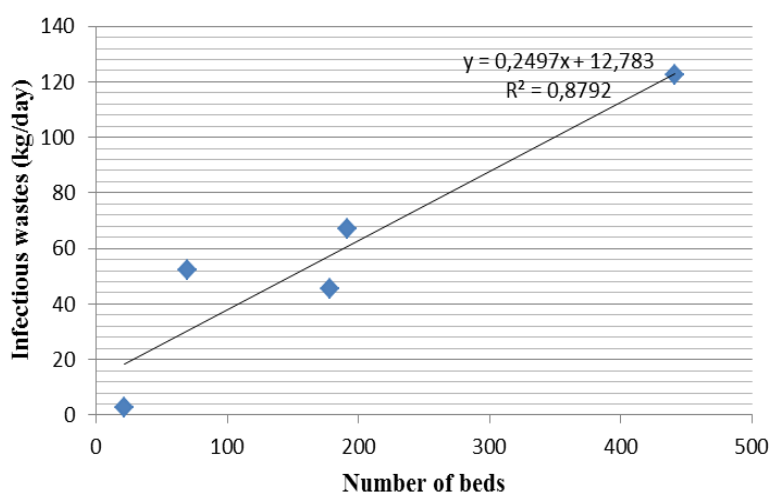

Fig.3. The correlation between infectious waste ( $\mathrm{kg} / \mathrm{day})$ with total of occupied beds (from 7 hospitals)

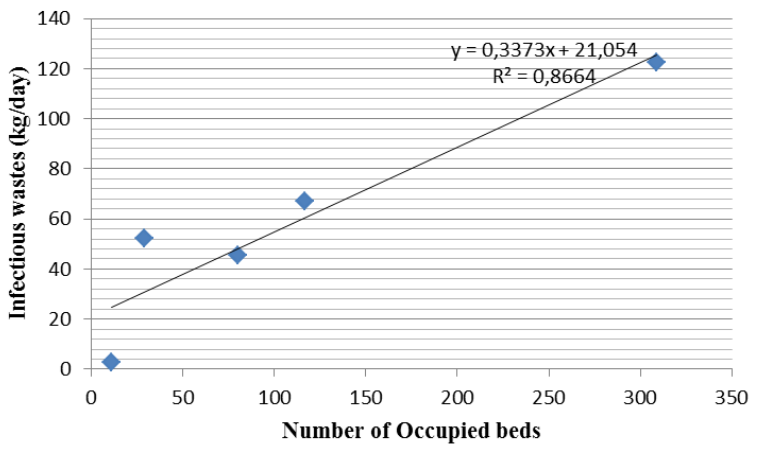

Fig.4. The correlation between infectious waste ( $\mathrm{kg} / \mathrm{day})$ with total of occupied of beds (general hospitals)

To predict quantities of infectious waste, an equation between variable independent (total of beds; total of occupied beds) and variables dependent (infectious waste generation rates $(\mathrm{kg} /$ day) can be recap from each scatter plot.

Table 2. Correlation between quantities infectious waste with number of beds and number of occupied bed

\begin{tabular}{|c|c|c|c|}
\hline Parameters & $\begin{array}{c}\text { coefficient } \\
\text { correlation } \\
(\mathrm{r})\end{array}$ & Regression & $\begin{array}{c}\text { Sig } \\
\text { (p-value) }\end{array}$ \\
\hline \multicolumn{4}{|c|}{$\begin{array}{l}\text { Average of infectious waste (kg/day) from } 7 \text { hospitals } \rightarrow \text { all } \\
\text { type hospitals }\end{array}$} \\
\hline Total of beds & 0,9329 & $y=0,265 x+6,1798$ & 0,000 \\
\hline $\begin{array}{c}\text { Total of } \\
\text { occupied bed }\end{array}$ & 0,9376 & $y=0,2407 x+12,783$ & 0,000 \\
\hline \multicolumn{4}{|c|}{$\begin{array}{l}\text { Average of infectious waste }(\mathrm{kg} / \text { day }) \text { from } 5 \text { hospitals } \rightarrow \text { general } \\
\text { hospital type only }\end{array}$} \\
\hline Total of bed & 0,9229 & $y=0,3624 x+13,669$ & 0,000 \\
\hline
\end{tabular}




\begin{tabular}{|c|c|c|c|}
\hline $\begin{array}{c}\text { Total of } \\
\text { occupied bed }\end{array}$ & 0,9308 & $\mathrm{y}=0,3373 \mathrm{x}+21,054$ & 0,000 \\
\hline
\end{tabular}

This results show there is a significant correlation between generations of infectious waste with number of occupied beds hospital. Table 3 presents a case where quantities of hospital infectious wastes ( $\mathrm{kg} /$ day) from 7 hospitals are estimated using (a) the formula $y=1,0579 x$ - 33,256 [6]; and (b) formula $y=0,2407 x+12,783$ (Table.4), the " $\mathrm{x}$ " are symbol from total of occupied beds. The average of infectious wastes ( $\mathrm{kg} /$ day) also tested using analysis of variance (anova) one way, to test is there any significant differ of average infectious wastes between survey result, formula a and formula $b$. The anova analysis shows that $p$-value is $0,777>0,05$ its means There are no significant difference between survey result, Sanida formula $y=1,0579 x-33,256$ and $y=$ $0,2407 x+12,783$ formula.

Table 3. Results of this study compared to Sanida estimations.

\begin{tabular}{|c|c|c|c|}
\hline $\begin{array}{c}\text { Hospital } \\
\text { Code }\end{array}$ & $\begin{array}{c}\text { Observed } \\
\text { results }\end{array}$ & $\begin{array}{c}\text { Sanida formula } \\
\mathrm{y}=1,0579-33,256\end{array}$ & $\mathrm{y}=0,2407 \mathrm{x}+12,783$ \\
\hline \multicolumn{4}{|c|}{ Average of hospital infectious waste (kg/day) from 7 hospitals } \\
\hline 1 & 67,17 & 90,52 & 40,94 \\
\hline 2 & 122,28 & 293,64 & 87,16 \\
\hline 3 & 52,05 & $-2,58$ & 19,76 \\
\hline 4 & 2,69 & $-21,62$ & 15,43 \\
\hline 5 & 14,7 & $-14,21$ & 17,12 \\
\hline 6 & 45,25 & 51,38 & 32,04 \\
\hline 7 & 16,58 & 27,04 & 26,50 \\
\hline Total & 320,72 & 424,16 & 238,95 \\
\hline Average & 45,82 & 60,59 & 34,14 \\
\hline
\end{tabular}

The most important phase from developing of risk analysis from infectious waste management is determined the infectious generation rates from Healthcare facilities. The domestic waste is produced from different services unit services at hospital, from non-medical activities such as: administration department, housekeeping, food product [7-8]. The infectious wastes had potential to transmission of diseases, contain pathogenic microbe, sufficient virulence that the doses enough to spread the diseases. From this study, the number of occupied beds have influence factor much better than only number of beds to produced infectious waste generation rates, yet in the field the ambiguity of definition infectious waste might lead to mismanagement of the waste and can affect the generation waste of infectious wastes and also affect the proportion of infectious wastes. The knowledge of healthcare facilities worker also need to improve continuously for good practice of infectious waste management.

\subsection{Proportion of infectious wastes}

Based on the calculation result, the average proportion of infectious waste based on the type of hospital between general hospital and specialized hospital is $36.9 \%$ and $29.4 \%$ gives $p$ value $0,101>0,05$ then $\mathrm{H} 0$ is accepted and $\mathrm{H} 1$ is rejected, hence can be concluded mean inflation waste proportion is not significantly different or same. Fig.8, Fig.9 and Fig.10. The recap of significant test is present at Table 4 . Based on hospital attribute the 7 hospital consists: (a) 1 hospital with A level ; (b) 2 hospital with B level; (c) 3 hospital C level; and (d) 1 hospital with D level. The proportion estimated by formula:

$$
T W=I W+D M
$$

Proportion Infectious waste $=(I W / T W) \times 100 \%$

$$
\begin{aligned}
& \text { IW }=\text { Infectious waste } \\
& \text { DW }=\text { Domestic waste } \\
& \text { TW }=\text { Total waste }
\end{aligned}
$$

To analyze the influence factor to the proportion infectious waste, the significant test using independent ttest and one way anova.

Table 4. Statistic recap for proportion infectious wastes based on hospital attribute

\begin{tabular}{|c|c|c|}
\hline $\begin{array}{c}\text { Independent } \\
\text { variable }\end{array}$ & \multicolumn{2}{|c|}{ Sig (p-value) } \\
\hline $\begin{array}{c}\text { Type of } \\
\text { hospital }\end{array}$ & 0,101 & p-value $>0,05$ \\
\hline $\begin{array}{c}\text { Level of } \\
\text { hospital }\end{array}$ & 0,001 & p-value $<0,05$ \\
\hline $\begin{array}{c}\text { Ownership } \\
\text { status }\end{array}$ & 0,807 & p-value $>0,05$ \\
\hline $\begin{array}{c}\text { Cleaning } \\
\text { service status }\end{array}$ & 0,002 & p-value $<0,05$ \\
\hline
\end{tabular}

The proportion of infectious wastes are varies greatly among hospital. For total infectious waste, plaboot or intravenous bag is the main source of infectious waste which is contains plastics and textile. Plaboot or intravenous bag proportion in total hazardous waste can reach $35,2 \%$ [9]. As shown at Table 6, the influence factors on proportion infectious waste are level of hospital and cleaning service status. Level hospital in Indonesia divided into 4 level (level A, B, C, and D). Determination of level hospital based on number of beds and the facility of treatment. The hospitals which had the most complete facility will gain level $\mathrm{A}$, and the lowest of type of treatment facility will gain level D.

Observation on the field reveals that visitors of hospitals in Bandung area less knowledge about 
segregation waste, especially between infectious waste and general waste. The visitor didn't aware about the differences of color the plastic bags. Sometimes the visitor of hospital put the general waste into yellow plastic bag. This condition obviously can cause the increasing of generation rates and proportion infectious waste at hospital. Beside visitors factor, quality of waste segregation depends on many factors, but its strongly relevant with employee involvement. Training program and socialization about segregation of hospital waste has improved segregation process, which has resulted in a significant reduction in the volume of healthcare waste and costs [10-11]. The improper of infectious waste management also can cause the increasing of generation and proportion of infectious waste, according to [12] awareness level from cleaning services status affected the hospital infectious waste management. To improve the proper hospital infectious waste management, Ministry of Environment and Forestry Indonesia trough government regulation No.P.56/MENLHK-SETJEN/2015 attached several chapters that contain the procedures about handling, treatment, reduce, reuse and recycling infectious waste, but unfortunately this regulation did not relevant with other government regulation from Ministry of Health Indonesia that mention any infectious waste cannot be reduce, reuse or recycling. This situation makes the healthcare facility management include hospital management confuse and finally prefer to follow the regulation from Ministry of Health Indonesia. Another problem of infectious waste management in Bandung region is the limitation of disposal and treatment facility. However, government commitment and support the proper implementation of infectious waste management for universal long-term environmental improvement.

At the end, the carbon factor will be associated with medical waste management. There are have been very limited number of studies that have looked at the carbon emission associated with medical waste management. From this study, it provide information to start infectious waste management strategy to reduce carbon footprint in the future

\section{Conclusions}

Respectively, the average of generation waste of total medical waste, infectious waste and general waste in Bandung area are 0,$91 ; 0,31$ and $0,60 \mathrm{~kg} / \mathrm{bed}$. Total proportion of hospital medical waste generated in Bandung area, $66,22 \%$ consisted of general waste and $33,77 \%$ infectious waste; The correlation and equation of infectious waste generation rate optimum at correlation coefficient 0,9376 with equation $y=0,240 x+12,783$ in this study. The comparison of amount proportion infectious waste among the seven studied hospitals showed significant differences at level hospital and status of cleaning service.

Based on this study, the current situation of infectious waste management in Bandung region urgently needs to improve the implementation in segregation process due to reduce the volume of infectious waste. The knowledge of cleaning service workers also need to improve by attends the training program. At temporary storage area, the infectious waste mostly getting overload that caused third party schedule. The limitations of third party to collected infectious waste become serious problem for infectious waste management. Government must take an action for alternative regulation and policy to prevent the overload capacity from hospital temporary storage. Most of the hospital temporary storage doesn't have air conditioner or freezer facility to maintain the temperature of the storage. The delay collection schedule from third party can affected the healthness of healthcare facility workers and patient and also affected the environment.

This study was funded by Ministry of Science and Technology Indonesia. The authors wish to thank all of the members of the survey team, analysis team and the hospitals that participated in the research.

\section{References}

1. WHO, Safe management of waste from health-care facilities 2nd edition, 3 (2014)

2. M. Tsakona, E. Anagnostopoulou, E. Gidarakos, Waste Management. 27, 912-920 (2007)

3. MenLHK (Ministry of Environment and Forestry). http://ppid.menlhk.go.id/siaran_pers/browse/1169. (2018)

4. Indonesia government regulation. PP no 101/2014. Management of Hazardous waste (2014).

5. N. Fitria, E. Damanhuri, I.R.S. Salami, Matec Web Conff SIBE, 147, 08004, (2018)

6. G. Sanida, A. Karagiannidis, F. Mavidou, D. Vartzopoulus, N. Maoussiopoulos, S. chatzopoulos, Waste management, 30, 532-538 (2010)

7. H. Taghipour, M. Mosaferi, Science of The Total Environment, 407, 1537-1535 (2009)

8. M. Chaerul, M.Tanaka, A.V. Shekdar, Waste management, 28, 442-449 (2008)

9. N. Fitria, E. Damanhuri, IWWG-ARB, Seminar publish (2017)

10. M. Mosquera, M.J.A. Prado, G.R. Caravaca, P. Latasa, M.E. Mosquera, American Journal of Infection Control, 42, 894-897 (2014)

11. G. Patil, K. Pokhrel, Waste Management, 25, 592599 (2005)

12. N. Fitria, E. Damanhuri, I.R.S. Salami, IOP Conf.Series : Earth and Environmental Science, 160, 012012 (2018) 